\title{
Managing Price Risk of Pork through Gross Margin: A Depiction from China and US
}

\author{
Phillip Daniel Daninga and Zhang Qiao
}

\begin{abstract}
China's demand for pork has been increasing at a relatively constant rate and its pork imports are increasingly determined by the fluctuations of its domestic supply. This fluctuation in domestic supply has resulted in making farmers suffer from the shocks of price instability. Despite the absence or underdevelopment of livestock insurance in most developing countries, an experience from China and US serves as a lesson for these countries to pay attention to the subsector with potential contribution to the country's economy but having little or no efforts accorded to the same. This study explored the importance of Livestock Gross Margin (LGM) insurance by analyzing the pork price fluctuation trend in China and linking the risk to the impacts on revenues of pork producers. The sources of data were national surveys reports, research papers and data obtained from China's Ministry of Agriculture (MoA). Findings revealed that Pork producers in China had been faced with adverse price fluctuations that posed threats to producers' revenues. The study shows LGM insurance as an important and alternative tool to smooth incomes of the producers in the pork industry when it is managed in its advanced stage. For pork industry to continue prospering, the study recommends establishment of reliable futures market to provide partial income risk insurance to producers whose output is risky.
\end{abstract}

Index Terms - Price fluctuation, Livestock Gross Margin Insurance, Pork Producers, Futures market.

\section{INTRODUCTION}

The global pig production sector has experienced a rapid growth over the last decades due to increasing demand of meat and meat products [1]. Pork production has globally increased by more than $80 \%$ from 1985 to 2010 with China's production of pork rising from 17.6 million to 51.7 million tons per year, hence accounting for half of the world's pig population [2]. Being a strategically important industry for China, hog production in the country is conducted by three categories of producers: backyard farms, specialized households and commercial farms [3]. While there is no strict definition of the three types of farms, backyard farms usually raise less than 50 hogs at one time, specialized farms raise 50 to 3,000 hogs and commercial farms raise more than 3,000 hogs in inventory [4], [5].

Demand for pork products in China has been growing steadily in this century and is predicted to continue to grow due to the steady rise in China's population and the urbanization of much of this population [6]-[8]. Chinese

Published on September 26, 2020

Phillip Daniel Daninga, The Mwalimu Nyerere Memorial Academy, Department of Economic Studies, Tanzania.

(corresponding e-mail: pdaninga ${ }^{\circledR}$ gmail.com)

Zhang Qiao, Research Centre of Agricultural Risk Management, Chinese Academy of Agricultural Sciences, China. consumers are believed to be fond of pork meat. While the market share of other kinds of meat, such as poultry, beef and mutton are rising, pork is still the leading meat in China [3]. In 2010 alone, farmers and companies in China produced more than 50 million metric tons of pork, virtually all of which was sold and consumed domestically [4]. The rapid growth in China's economy which continue to increase income and improve living standards, urban consumers becoming affluent and the rapid increase in urbanization are among the factors that influence the China's development of pork industry [3]. This Chinese pork boom is the result of a set of policies and trade agreements that liberalized and industrialized Chinese agriculture and enabled enormous production increases [4], [9], [10]. However, China's demand for pork has been increasing at a relatively constant rate and its pork imports are increasingly determined by the fluctuations of its domestic supply [4]. Cyclical oversupply and nonprofitability situations have led to pig industry consolidations in the People's Republic of China, with many smaller farmers leaving the industry [7]. The fluctuation in domestic pork supply is caused by a number of reasons including fluctuations in pork prices due to high prices of feed ingredients (cereals and soybean) that create cost-ofproduction issues, eruption of some complex disease issues like the highly virulent porcine reproductive and respiratory syndrome, porcine circovirus and classical swine fever as well as recent natural disasters (earthquakes/freezing winters) (ibid).

To help farmers, some measures have been adopted by the government of China in an attempt to solve the problem of price instability [11]. For instance, China has a pork price monitoring system whereby a hog-to-corn price ratio of six is considered to be a break-even level for pig farmers and is used as a gauge to check if Chinese pork supply is stable and to get a better sense of farmer's income [12]-[14]. If the ratio raises over nine, the government might release more pork into the market, and if it falls below six, then it could purchase pork to stabilize prices. Authorities have also instigated many helpful measures over the past decade, including insurance for farm breeder stock, direct subsidies for farm expansions and breeding programmes, free supplies of some vaccines, and taxation exemptions. Despite this role of Chinese government to regulate the market prices, the efforts have not been a panacea to individual farmers who face losses due to price variability. The decrease in profitability is caused by decline in swine prices and/or increased feeding or input costs hence narrowing the feeding or finishing margin.

Farm prices and Farm Wholesale (FW) margins are very much related for livestock producers [15]. While changes in 
livestock prices can be caused by consumer demand, farm supplies, marketing costs, market power of agribusiness firms, and international trade, changes in Livestock prices can influence farm prices and FW margins [16]. Over supply of any commodity lowers the demand consequently lowering the price of the commodity. Increase in prices of farm supplies (feed) as well as the marketing costs elevates the cost of production consequently narrowing the feeding margins. To overcome the increased feed costs, livestock prices skyrocket which in turn affects the demand hence lowering the pork producers' profits. Incidence of livestock diseases and other livestock and food safety scandals [2] can affect the international trade, lower the demand of livestock and adversely affect the market prices of livestock which ultimately leads to farmers experiencing major losses or reduced profits.

Gross Margin insurance for swine is a kind of insurance that provides revenue protection to pork producers and is specifically designed to help protect pork producers' profit margin [17]. The farmer receives benefits when the difference between hog prices and feed costs at the time his/her hogs are sold is less than the gross margin guarantee for the coverage period. Expected prices for hogs are set by the lean hog futures. In this program, corn and soybean meal prices are set by futures market. A certain amount of hogs can be insured during each insurance period, while farmers may select different levels of coverage of the expected margin. In each calendar year there is an insurance period whereby each insurance period runs for a predetermined number of months.

While the hog market in China is doing well, the lack of relevant tools to insulate farmers from the risk of low profitability due to narrow feeding margins continues to be a challenge in China [18]. The pertinent policy question remains to be: are small and large scale swine producers in the country insured against the narrow finishing margins caused by downside hog price fluctuations and rising input costs? This paper explores the importance of LGM insurance by analyzing the pork price fluctuation trend in China and linking the risk to the impacts on revenues of pork producers.

\section{METHODS}

This study explored the importance of Livestock Gross Margin (LGM) insurance by analyzing the pork price fluctuation trend in China and linking the risk to the impacts on revenues of pork producers. The sources of data were national surveys reports, research papers and data obtained from China's Ministry of Agriculture (MoA). An analysis of live swine prices in China was done using swine prices data from 2006 to 2013. Monthly pork prices were implored from the ministry and computed to establish the average annual price for each year. Microsoft Excel 2010 was used as an analytical tool to analyze the 7 years price fluctuation trends in the country. A review analysis of the literature was employed to present the swine market and trade in China, the operationalization of Livestock Gross Margin (LGMswine) in the US as well as the Gross Margin insurance status in China and United States.

\section{RESULTS AND DISCUSSION}

\section{A. China's Pork Market and Trade}

The per capita pork consumption has increased in both urban and rural China in the past three decades, making it to be the primary meat in the Chinese diet for thousands of years now [5]. The per capita pork consumption for example, increased from $16.68 \mathrm{~kg}$ in 1985 to $20.50 \mathrm{~kg}$ in 2009 in urban China, and increased from $10.54 \mathrm{~kg}$ in 1990 to $13.96 \mathrm{~kg}$ in 2009 in rural China. Despite the significant per capita poultry consumption increase, pork is still the primary meat in the Chinese diet. In 2010 for example, pork accounted for about $60 \%$ of per capita meat consumption in urban areas and $71 \%$ of per capita meat consumption in rural areas. Figure 1 presents the details of the increase in China's pork production. The number of slaughtered hogs increased $151 \%$, from 257.2 million heads in 1986 to 645.4 million heads in 2009. At the same time, pork output increased $172 \%$, from $17.96 \mathrm{mmt}$ in 1986 to $48.9 \mathrm{mmt}$ in 2009. The difference in increase percentages indicates that pork production per hog increased over the period.

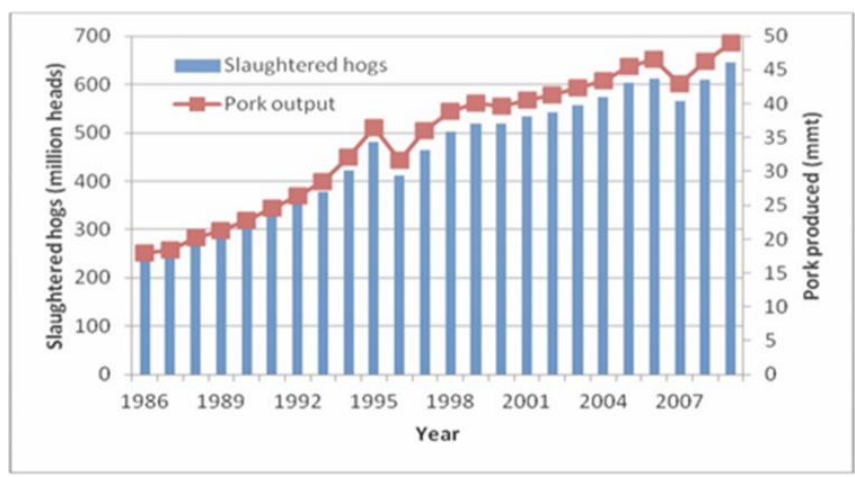

Fig. 1. China's annual pork output, 1986-2009 [7].

Three factors have influenced the development of the China's pork industry. First, rapid growth in China's economy has continued to increase income and improve living standards. More and more urban consumers have become affluent and showing similar consumption patterns to the U.S. consumers. Rapidly increasing income and urbanization has generated new market opportunities for quality pork products. The rapid growth in China's economy which continue to increase income and improve living standards, urban consumers becoming affluent and the rapid increase in urbanization are among the factors that influence the China's development of pork industry.

It is revealed further that, the private sale of pigs was first permitted in 1975, and private control over pig and pork prices and pig purchases was first introduced in 1985 [7] which led to a rapid rise in pig ownership and farming. Conversely, by the mid-1990s a major oversupply resulted into pig farming becoming unprofitable. After that, industry consolidation followed and many small holder farmers were seen leaving the industry. Once again in 2005 and 2006, low pig farm profitability resulted in farm closures and many rural farmers had to move to work on urban construction projects. By 2007, high level of diseases caused the supply shortage to worsen further causing many pigs to be taken out of the supply chain in 2007 hence causing rapid rises in pork prices and restricted access to pork for many people 
[19]-[21].

In 2007/2008, the very long and cold winter in the hilly south-east provinces of Guangxi, Hunan and Jiangxi, affected the many local key breeder farms, killing approximately one million pigs [7]. The affected breeder farms could not fully supply young growing pigs to the adjacent Guangdong farms and markets. Again, in May 2008 , the Sichuan earthquake led to the loss of an estimated four million growing pigs, which, however, was only suggested to lower Sichuan Province pork production by between $2 \%$ and $4 \%$ in 2008 .

\section{B. Pork Price Trends in China}

Pork producers' incomes had not been stable due to fluctuations in pork prices in China. Findings from this study show that, the pork prices in China had been unstable with a decreasing trend. As presented in Fig. 2, pork prices fell from 20 Yuan per Kg in 2011/12 to nearly 20 Yuan per $\mathrm{Kg}$ in 2013/14 (Yuan = renminbi (RMB). US\$1 =6.6 RMB).

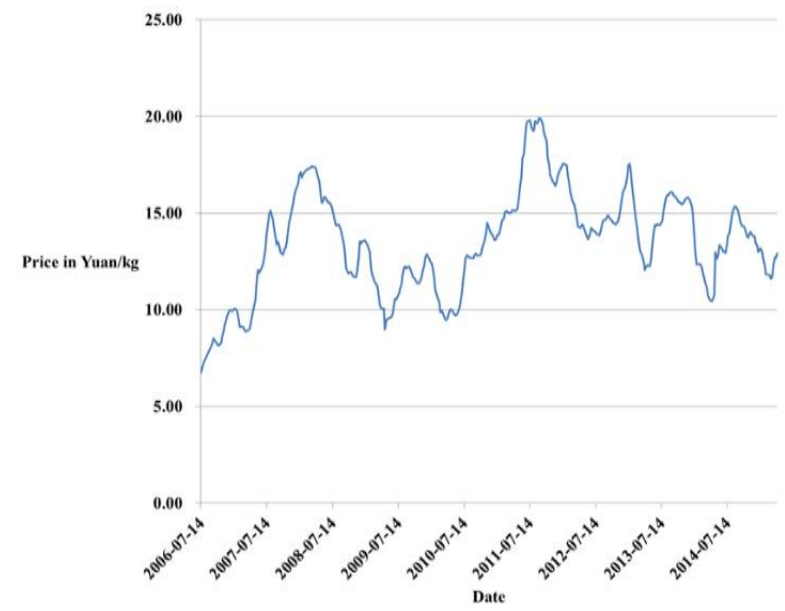

Fig. 2. China's National average live pig price. Source: MoA.

Records for example show that Chinese food inflation was up 2.7 percent year-over-year in March 2013, down from six percent the previous month (Fig. 3) [22]. This decline was led by a 5.5 percent decline in pork prices. The year 2013 saw pork prices falling since the Lunar New Year holiday. It was also revealed by the Bank of America that pork prices would continue staying weak in months after March 2013 due to some reasons. Firstly, sow breeding inventory had been at a "historically high level at around 20.7 million since September 2012. The high inventories had an implication of high supply which is inversely related to prices of pork. Also, corn was an important feed grain for pigs, but the corn prices had declined. As reported by Badkar [22], the hog-to-corn price ratio was below 6, "roughly a break-even level for pig farmers". A lower ratio suggested that pork profitability had declined and that rational farmers would see it more sensible to sell corn instead. The Bank of American Meryl Lynch (BAML) further predicted that due to falling share prices on pork demand, it was likely that pig farmers would slash existing inventories of both breeding sows and hogs for slaughtering, an attempt that could accelerate pork price decline.

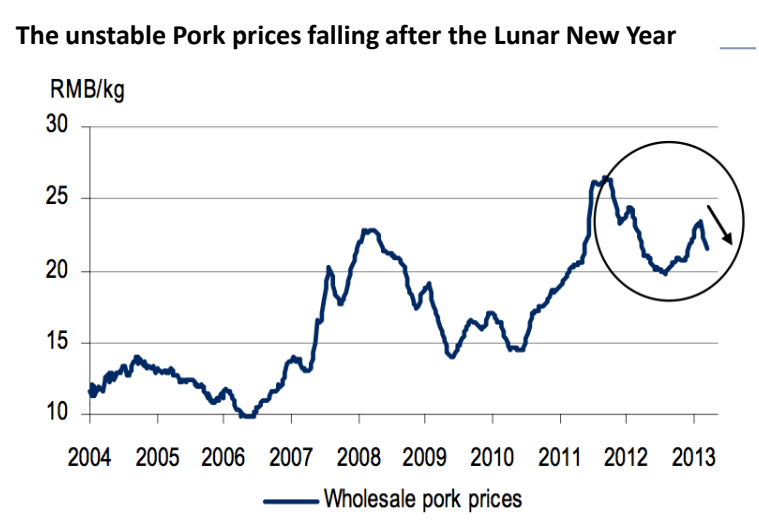

Source: BAML, 2013

Fig. 3. China's unstable swine price trend.

However, although the government of China has been so involved in solving the problem of price fluctuations, it is clear that hog prices had never been stable in favour of pork producers' profitability. Likewise, prices of farm supplies like livestock feeds varied overtime hence narrowing the feeding margins. Soybeans and corn demand were one of the reasons towards this variability in pork feed costs. While soy is particularly important in commercial pig feed mixes, corn is the most used feedstuff for smallholder and specialized household farmers [4]. Furthermore, Corn is protected as a "strategic crop for food security," mainly because it is used as a staple food for human consumption. Of recent, corn has been used in the manufacture of industrial products as well as increasingly livestock feed. For these reasons, China became a net corn importer in 2010 for the first time since 1995, making buyers, a state-owned conglomerate and a private agribusiness firm to produce feed. As claimed by authorities, supplies of corn and soy in 2010 were inconsistent, explaining the reason for higher feed prices in the market. On the other side the problem with pork price instability is that producers face asset value and equity losses as livestock prices fall drastically [23]. The major problem faced by pork producers due to adverse price fluctuations was lower profits caused by increased input costs that cause the feeding or finishing margins to narrow. Smallholder farmers were particularly affected hence increasing their vulnerability to poverty. Gross margin insurance could prove to be so helpful to pork framers in stabilizing their incomes. However, this kind of index insurance in China is still uncommon.

\section{GRoss MARgin InSURANCE For Swine: A DEPICTION FROM LIVESTOCK GROSS MARGIN INSURANCE PROGRAM IN UNITED STATES}

\section{A. Livestock Gross Margin insurance}

The importance of protecting farm equity to agricultural industries and rural economies cannot be overstated. In many livestock producing regions, such as the Great Plains, regional economies are driven by the jobs and wealth created by livestock production and related activities [23]. Without the equity of livestock producers to finance producers' purchases of goods, services and capital 
equipment, rural communities would suffer further outmigration and declining economic fortunes. This is the reason the US has done much to help pig producers overcome the problem of price downfalls and income instability by devising appropriate tools such as Livestock Gross margin (LGM) insurance program. Livestock Gross Margin (LGM) is an insurance product under the federal crop insurance program that offers protection against a decline in the feeding margin for cattle and swine and is reinsured by the Federal Crop Insurance Corporation [24].

LGM insurance provides protection against loss of margin and is available for swine, cattle feeders and dairy producers [25], [26]. LGM-Dairy for example, uses futures prices for corn, soybean meal, and milk to determine the expected gross margin and the actual gross margin [27]. In this program, there is no minimum on number of hundredweights to be insured. The LGM-Swine applies to farrow-to-finish operations, feeder pig-finishing operations, and segregated early weaned (SEW) operations, and calculates gross margin by market value of livestock minus feed costs. The gross margin for LGM-Cattle (for yearling and calf finishers) is obtained by factoring in the market value of livestock minus feeder cattle and feed costs [28].

In the United States of America, the Livestock Gross Margin insurance for Swine (LGM-Swine) is an insurance policy that was first offered in 2002 as a pilot study in Iowa under USDA's Risk Management Agency (RMA) [19]. In this program, corn and soybean meal prices are set by the Chicago Board of Trade futures. While up to 15,000 hogs can be insured during each insurance period, farmers may select a level of coverage of $80 \%, 85 \%, 90 \%, 95 \%$ or $100 \%$ of the expected gross margin. There are twelve insurance periods in each calendar year. Each insurance period runs six months and no swine can be insured the first month of any insurance period. Coverage begins on producers' swine one full calendar month following the sales closing date (unless otherwise specified in the Special Provisions), provided that the premium for the coverage has been paid in full. For example, for the contract with a sales closing date of January 31, coverage has to begin on March 1 (ibid).

\section{B. Operationalization of LGM-swine}

The LGM-swine provides protection against a decline in Swine finishing margins by simultaneously hedging the corn and soybean meal input costs and the swine selling price as bundled option [30], [31]. The innovation of this contract is twofold. First, the insurance contract is dealing with margin and second, the insurer is using futures markets for reinsuring the transferred risk [17]. In their edition, Mark et al [30] explains in details how the LGM-swine operates in United States. They assert that while LGM is based on the futures market prices and provides protection similar to a bundled option on futures contracts, producers using LGM take no futures or options themselves and therefore do not need brokerage account but must however purchase the policy through a licensed crop insurance agent. The LGM for swine is offered for farrow to finish, feeder pig finishing, and segregated early weaned (SEW) pig finishing operations.

Essentially the LGM insurance pays insured producers an indemnity when the swine sales price and soybean meal and corn input prices narrow beyond their insured coverage level due to changing market conditions. As this feeding margin narrows, the corresponding indemnity payment becomes larger to offset lower revenues and/or increased costs. Indemnities payments are based on a gross margin guarantee (GMG) and a total actual gross margin (AGM). The GMG is the livestock feeding margin producers insure when they purchase the swine policy. It is based on the expected swine prices, soybean meal prices and corn prices in the policy. The total AGM is the livestock feeding margin that occurs due to realized, actual prices observed in the market after six months swine coverage period. At the end of insurance period, an indemnity is paid to the producer if the insured GMG for the period exceeds the total AGM. The swine and corn prices used to compute the GMG and AGM for swine are based on the futures prices adjusted for state and monthspecific levels. However, the soybean meal prices used for computing the GMG and AGM for swine are based only on futures prices with no base adjustment.

\section{Insurance Period under LGM-swine}

LGM for swine is available for purchase on the second to last business day of the month. So, there are 12 LGM sales period per year. Each of these has an insurance period of 6 months, so swine to be marketed up to 6 months from the sales closing date can be insured. Coverage begins one full month after the sales closing date, provided the premium for the policy has been paid in full at the time of purchase. No livestock sales are insurable during the first month of any insurance period. For example, if a producer purchased a policy on a sales closing date of January 31, no target marketing will be insurable until March 1 . This restriction is to prevent adverse selection. Because the first month of the insurance period is so near, producers could have an idea of whether an indemnity would be due based on prices for those months. Producers could produce one policy to cover the entire insurance period or obtain multiple policies with sales closing dates in different months. For example, producers wanting to ensure swine from March to August could insure all six months with one policy purchased at the end of January. Alternatively, they could purchase coverage for each month separately, that is, buying March coverage in January or before, April coverage in February or before and so on. Any combination of these two transactions could occur. Insurance that is purchased on more deferred months generally receives the most protection against changing margins because future input prices are hedged in addition to swine sales.

\section{Eligibility for LGM insurance and qualifying livestock}

To be eligible for LGM insurance, applicants must have substantial beneficial interest (SBI) in the insured livestock. SBI is tracked in the LGM program because there is limits to the number of livestock anyone producer can insure with LGM insurance during specific time period. To have SBI, the producer must have at least $10 \%$ ownership of the insured livestock. If the applicant has a spouse, the spouse typically is considered to have SBI in the applicant's livestock, unless specific conditions, as outlined by the Federal Crop Insurance Corporation (FCIC) procedures and provisions, can be proven. Livestock eligible to be insured 
with LGM policy must be expected to have certain weight specifications and be on feed for a certain amount of time before they are marketed. Livestock must be expected to meet certain weight, time, and feed requirements. However, if livestock do not exactly meet the expectations outlined in the policy, LGM coverage is not affected nor is the right to an indemnity. The livestock specification in the policy allows inclusion of livestock under many common feeding situations.

Three different types of operations are insurable with LGM-swine. A farrow to finish operation assumes that pigs will be marketed at $250 \mathrm{lbs}$ (live weight basis) and consume 13.86 bushels of corn and 196.16 lbs of soybean meal $(9.808$ percent of one ton of soybean meal per head). Feeder pig finishing and SEW pig finishing operations also are assumed to finish swine to $250 \mathrm{lbs}$ (live weight basis, Lbs=pound, $1 \mathrm{Kg}=2.205 \mathrm{lbs}$ ). In the feeder finishing operation, hogs are assumed to eat 9.6 bushels of corn and $132 \mathrm{lbs}$ of soybean meal (6.6 percent of one ton of soybean meal) per head. The SEW pig finishing operation assumes that each hog consumes 9.7 bushels of corn and $142 \mathrm{lbs}$ of soybean meal (7.1 percent of one ton of soybean meal). The weights and averages used to establish the type of operation are based on industry averages.

\section{E. Purchasing coverage and contract size}

Once producers have been approved for coverage, and substantial beneficial interest has been proven, target marketing is established. Target marketing represents the number of slaughter- ready swine that are expected to be marketed during the insurance period and that the producer wants to insure with LGM. A specific number of swine are insured for each target month in 6 month insurance period. Producers are not required to ensure all livestock they plan to feed and sell, and can insure any number of livestock up to program limit. Target marketing insured cannot exceed a producer's approved target marketing. Approved target marketing are the maximum number of livestock that can be stated as target marketing on the insurance application and are based on a lesser of farm capacity or underwriting capacity for the insurance period as determined by the insurance company. LGM is available for purchase from any authorized crop insurance agent licensed to sell LGM.

Producers are not required to ensure all livestock they plan to own and sell. Swine producers can insure any amount of swine up to a program limit of 15,000 head for any 6-month insurance period and a limit of 30,000 head per crop year. There is no limit to the number of LGM policies producers can purchase; only the number of head insured is limited. Livestock could be insured using multiple policies during one crop year as long as a producer does not exceed the 30,000 head policy limit for swine. Because only the maximum number of head insured is limited and producers can ensure any amount of livestock up to the program limits, LGM is useful to producers with smaller feeding or finishing operations who may lack enough livestock to effectively use futures and options to hedge price risk.

\section{USEFULNESS OF LGM IN PRICE RISK PROTECTION}

LGM is a price risk management tool which offers useful protection by protecting the gross feeding margin. Although it is not designed to be a price capture mechanism or profit enhancer, the program is more useful in preventing large, potentially devastating losses to operation in an event of narrowing feeding or finishing margin caused by lower revenues and/or increased input costs. A narrowing swine finishing margins could be the result of decreasing live swine prices and/or increasing soybean meal or corn prices. Movement in one, two or all three of these markets could cause the feeding or finishing margin to narrow. On the other hand, a large adverse price moves in one of the markets for example soybean meal may not trigger a decreased margin and subsequent indemnity if another market for example lean hogs moves favorably. LGM for swine protects lean hogs, soybean meal, and corn price changes. However, even though price is reduced with this coverage, it still has some limitations as it does not protect against basis risk or performance or production risk including death loss.

\section{IMPORTANCE OF FUTURES OR OPTIONS TO SMALL SCALE PRODUCERS}

A futures exchange or futures market is a central financial exchange where people can trade standardized futures contracts; that is, a contract to buy specific quantities of a commodity or financial instrument at a specified price with delivery set at a specified time in the future. These types of contracts fall into the category of derivatives. Such instruments are priced according to the movement of the underlying asset (stock, physical commodity, index, etc.). Futures markets "provide partial income risk insurance to producers whose output is risky, but very effective insurance to commodity stockholders at remarkably low cost. Speculators absorb some of the risk but hedging appears to drive most commodity markets. The equilibrium futures price can be either below or above the (rationally) expected future price.

Futures and options contracts cover fixed amounts of commodities. For example, one fed swine contract is 40,000 lbs, one corn contract represents 5,000 bushels and one soybean meal equals 100 tons. Many times, these amounts are too large to be used effectively for risk management portfolios for smaller feeding operations. Swine producers for instance may not purchase enough pigs to cover one fed swine contract or enough corn to represent 5,000 bushels for a particular target marketing month. This in turn, leaves the producer exposed to the more risk because the producer is hedging more than is actually being purchased in the cash market. In addition, the difficulty in using futures or options is compounded by the ration producers would need to equalize lean hogs, soybean meal and corn contracts according to production practices so as to not over or under hedge one or more commodities in these three ways spread. The LGM policy combines the three commodities in an equivalent fashion for the producers, so they do not have to purchase multiple contracts to be hedged in each commodity. Because there is no minimum number 
of head to insure with LGM, producers with smaller sized operations can use LGM without hedging more swine than they plan to sell.

\section{CONCLUSION AND RECOMMENDATIONS}

Pork producers in China had been faced with adverse price fluctuations. The adverse price variations have potentials to increase farmers' vulnerability to poverty due to lower profits. As a risk hedging tool, Livestock Gross Margin Insurance could prove to be so helpful to pork framers in stabilizing their incomes. Although this kind of index insurance in China is still uncommon, the position of swine industry in China's economy remains to be immense. If swine producers in China are insulated from variety of risks that undermine their incomes, this will provide a secured supply of the preferred meat for the expanding population both in urban and rural areas in China. China must provide alternative tools to hedge pork producers from price and income risks. Gross margin insurance is a price risk protection tool which is yet to be in its advanced development in China. For the industry to continue to prosper, it is recommended that China must introduce pork farmers into the futures market where their feeding margins can be insured hence stabilizing the pork industry by enhancing producers' profits. Despite its limitations, gross margin insurance is useful in preventing large, potentially devastating losses to operation in an event of narrowing feeding or finishing margin caused by lower revenues and/or increased input costs. The pros and cons in the studied area provide bases for need to establish and develop the swine markets relevant to growing economies of developing countries like Tanzania.

\section{REFERENCES}

[1] Fournie, G., Kearsley-Fleet, L., Otte, J., and Pfeiffer, D. (2012). Trends in the emergence of swine pathogens. Food and Agricultural Organization of the United Nations, Regional office for Asia and the Pacific.

[2] Haley, U. C. V. (2013). "Testimony of Usha C. V. Haley Professor/Director, Robbins Center for Global Business and Strategy, West Virginia University before the U.S. senate committee on agriculture, nutrition and forestry," Washington, DC. www.ag.senate.gov/download/?id=272864a7-2e92-4125-91e8 (accessed on August 26, 2013).

[3] Pan, C., and Kinsey, J. (2002). "The supply chain of pork: US and China," Food Industry Center, University of Minnesota.

[4] Schneider, M. (2011). Feeding China's Pigs. Institute for Agriculture and Trade Policy.

[5] Wang, Q., and Zhang, G. (2012). China's small-scale hog production and implications for trade: Evidence from a farmer survey. In "2012 Annual Meeting, August 12-14, 2012, Seattle, Washington". Agricultural and Applied Economics Association.

[6] He, Y., Yang, X., Xia, J., Zhao, L., \& Yang, Y. (2016). Consumption of meat and dairy products in China: a review. Proceedings of the Nutrition Society, 75(3), 385-391.

[7] McOrist, S., Khampee, K., and Guo, A. (2011). Modern pig farming in the People's Republic of China: growth and veterinary challenges. Revue scientifique et technique (International Office of Epizootics) 30, 961.

[8] Wang, J., Chen, Y., Zheng, Z., \& Si, W. (2014). Determinants of pork demand by income class in urban western China. China Agricultural Economic Review.

[9] Schneider, M. (2017). Wasting the rural: Meat, manure, and the politics of agro-industrialization in contemporary China. Geoforum, 78, 89-97.
[10] Xiong, C., Liu, C., Chen, F., \& Zheng, L. (2017). Performance assessment of food safety management system in the pork slaughter plants of China. Food control, 71, 264-272.

[11] Dong, X., Brown, C., Waldron, S., \& Zhang, J. (2018). Asymmetric price transmission in the Chinese pork and pig market. British Food Journal.

[12] Tao, H., \& Xie, C. (2015). A Case Study of Shuanghui International's Strategic Acquisition of Smithfield Foods. International Food and Agribusiness Management Review, 18(1030-2016-83059), 145-166.

[13] Wan, W. (2014). Farmers'willingness To Pay for Breeding Sow Insurance: Evidence from China's Hubei Province. Theses and Dissertations--Agricultural Economics. 22 https://uknowledge.uky.edu/agecon_etds/22.

[14] Zhang, Y. (2018). Can Farming Make Money? In Insights into Chinese Agriculture (pp. 95-115). Springer, Singapore

[15] Marsh, J. M., \& Brester, G. W. (1999). Technological Change in the US Beef and Pork Sectors: Impacts on Farm-Wholesale Marketing Margins and Livestock Prices (No. 1121-2016-91903).

[16] Marsh, J. M., and Brester, G. W. (2003). Technological Changes in Beef and Pork Production: Effects on Marketing Margins and Prices. Choices 18.

[17] Cordier, J., and Phélippé-Guinvarc'h, M. (2010). An option of the average European futures prices for an efficient hog producer risk management. Revue d'Etudes en Agriculture et Environnement 91 $27-42$.

[18] Pelletier, N., Lammers, P., Stender, D., \& Pirog, R. (2010). Life cycle assessment of high-and low-profitability commodity and deepbedded niche swine production systems in the Upper Midwestern United States. Agricultural Systems, 103(9), 599-608.

[19] McOrist, S., and Done, S. (2007). High fever swine disease impacts in asia. J Swine Health Prod 15, 319-319.

[20] Tian, K., Yu, X., Zhao, T., Feng, Y., Cao, Z., Wang, C., Hu, Y. Chen, X., Hu, D., and Tian, X. (2007). Emergence of fatal PRRSV variants: unparalleled outbreaks of atypical PRRS in China and molecular dissection of the unique hallmark. PLoS one 2, e526.

[21] Zhang, J., and Trachtenburg, E. (2007). "China, People's Republic of: livestock and products. Annual report.," Rep. No. CH7076. Foreign Agricultural Service, United States Department of Agriculture,, Washington, DC.

[22] Badkar, M. (2013). Pork Prices Are Falling In The World's Largest Pork Market. In "Business Insider, April 8, 2013", http://www.businessinsider.com/pork-prices-are-falling-in-china2013-4 (accessed August 23, 2013).

[23] DeVuyst, C. S., and DeVuyst, E. A. (2005). Indemnifying Asset Value Losses Related to Livestock Disease Announcements. Western Economics Forum 04.

[24] Boetel, B. (2011). "LGM: Livestock Gross Margin Insurance." UW Extension Wisconsin Beef Information Center, Wisnconsin.

[25] Babcock, B. A. (2004). Implications of extending crop insurance to livestock (No. 1448-2016-119517).

[26] Horner, J., Milhollin, R., Massey, R., \& Bock, B. (2018). Livestock gross margin (LGM) insurance in Missouri

[27] USDA/RMA (2011). Livestock Gross Margin Dairy Cattle. In "A Risk Management Agency Fact Sheet". United States Department of Agriculture, Washington, DC.

[28] USDA/RMA (2012). Livestock gross margin insurance plan for swine. In "A Risk Management Agency Fact sheet". United States Department of Agriculture, Washington, DC.

[29] Waterbury, J. A., Small, R. M., and Mark, D. R. (2007). Livestock Gross Margin Insurance for Swine. Cornhusker Economics, 326

[30] Mark, D. R., Waterburry, J. A., and Small, R. M. (2007). "Livestock Gross Margin Insurance: A self Study Guide," The Board of Regents of the University of Nebraska, Lincon, USA.

[31] van Asseldonk, M., \& Meuwissen, M. (2017). Gross margin insurance on Dutch dairy and fattening pig farms (No. 2017-026). Wageningen Economic Research. 